\section{Association Between Pollen Exposure and Nasal Cytokines in Grass Pollen-Allergic Children}

Di Cara $\mathrm{G}^{1}$, Panfili $\mathrm{E}^{1}$, Marseglia $\mathrm{GL}^{2}$, Pacitto $\mathrm{A}^{1}$, Salvatori $\mathrm{C}^{1}$, Testa $\mathrm{I}^{1}$, Fabiano $\mathrm{C}^{3}$, Verrotti $\mathrm{A}^{3}$, Latini $\mathrm{A}^{1}$

${ }^{1}$ Università degli Studi di Perugia, Dipartimento di Scienze Chirurgiche e Biomediche, Perugia, Italy

${ }^{2}$ Unità di Pediatria Generale e Specialistica,Dipartimento di Scienze Clinico-Chirurgiche Diagnostiche e Pediatriche, Fondazione IRCCS Policlinico San Matteo di Pavia, Pavia, Italy ${ }^{3}$ U.O.S.D. Pediatria D.U. e Pronto Soccorso Pediatrico, Dipartimento Materno Infantile, Università degli Studi dell'Aquila, L'Aquila, Italy

J Investig Allergol Clin Immunol 2017; Vol. 27(4): 261-263 doi: $10.18176 /$ jiaci.0161

Key words: Grass pollen. Children. Allergic rhinitis. Nasal cytokines.

Palabras clave: Polen de gramíneas. Niños. Rinitis alérgica. Citoquinas nasales.

Allergic rhinitis (AR) is the most common chronic disorder in the pediatric population, with up to $40 \%$ of children affected [1]. AR and its comorbidities have a profound impact on the daily lives of children, yet the disease remains underdiagnosed and undertreated in this group [2].

The Allergic Rhinitis and its Impact on Asthma (ARIA) guidelines classify rhinitis into AR and nonallergic rhinitis based on the presence and absence of allergic sensitization. $\mathrm{AR}$ arises due to IgE-mediated mechanisms and is usually characterized by a typical cellular inflammatory pattern in the nasal mucosa involving eosinophils and mast cells.

A recent study on nasal cytology demonstrated a close relationship between increased counts of eosinophils and mast cells and pollen exposure in Parietaria-sensitized adults, with cell counts better reflecting inflammation, and thus clinical symptoms, than the pollen count itself [3].

However, nasal cytology is used less commonly in children than in adults, often because of poor cooperation by the pediatric patient. Moreover, the increase in nasal inflammatory cells is more influenced by other confounding factors such as infectious agents.

Nasal mediators in nasal lavage fluid have been evaluated in clinical practice to validate allergen-specific nasal challenges, in which levels of eosinophil cationic protein (ECP) and tryptase are used as markers of immediate and delayed inflammation. Both correlate well with allergen exposure [4,5].

The role of these mediators in clinical practice has yet to be completely defined, although the identification of new types of rhinitis, such as local AR, highlights their potential importance in both diagnosis and follow-up [6].

We studied children sensitized to grass pollens to compare the relationship between pollen exposure and eosinophils and mast cell cytokines (ie, ECP and tryptase), which was evaluated using a nasal incubation method to verify the potential of these markers for monitoring nasal inflammation in a pediatric population.

The study population comprised 38 children (23 boys, 15 girls; mean age, 11.5 years) diagnosed with AR according to the ARIA guidelines, a positive skin prick test result for grass pollen, with negative results for the other common aeroallergens, and clinical symptoms consistent with sensitization during the previous pollen season. Skin prick test results were considered positive if the wheal diameter exceeded $5 \mathrm{~mm}$. The exclusion criteria were a previous history of specific immunotherapy (subcutaneous or sublingual), a diagnosis of nonallergic rhinitis, presence of other diseases (chronic, immunologic, and hematologic-oncologic), and sensitization to other allergens.

Nasal cytokine sampling: Nasal tryptase and ECP sampling was performed using ELISA (UniCAP Tryptase System FEIA and UniCAP ECP System FEIA, Pharmacia) adapted for mucosal sampling based on a method described elsewhere [5-6].

All children were sampled every 2 weeks before the beginning and after the end of the pollen season (March 1, 2014 to September 30,2014). The nasal tests were accompanied by recording of the clinical symptom score.

Grass pollen count: We recorded 22 mean weekly grass pollen concentration values and peaks (grains/m3 of air) in Perugia, Italy between March 1, 2014 and September 30, 2014. The pollen season started on April 23 and ended on June 27, with 2 pollen peaks in the second and third weeks of May and in the first 2 weeks of June. In 2014, an unusual peak was also observed in the pre-autumn period, with a lower pollen peak from the fourth week of August to the second week of September.

Evaluation of nasal symptoms: Clinical symptoms were evaluated using the Rhinoconjunctivitis Total Symptom Score (RTSS). Each patient scored 6 individual rhinitis symptoms on a 4-point scale. Scores ranged from 0 to 18 , with higher scores indicating more severe allergy symptoms.

Nasal ECP levels began to increase at the beginning of April and persisted until the end of June, with mean values always present during exposure; a second increase in ECP values was observed between late August and September (Figure, A). Nasal tryptase levels were more variable, better reflecting the pattern of pollen concentration in each of the months studied, with higher peaks during the 2 pollen peaks (Figure, B).

RTSS values were higher during both pollen peaks (7.12 [2.14] and 7.84 [3.27]). A smaller increase in the RTSS 
A

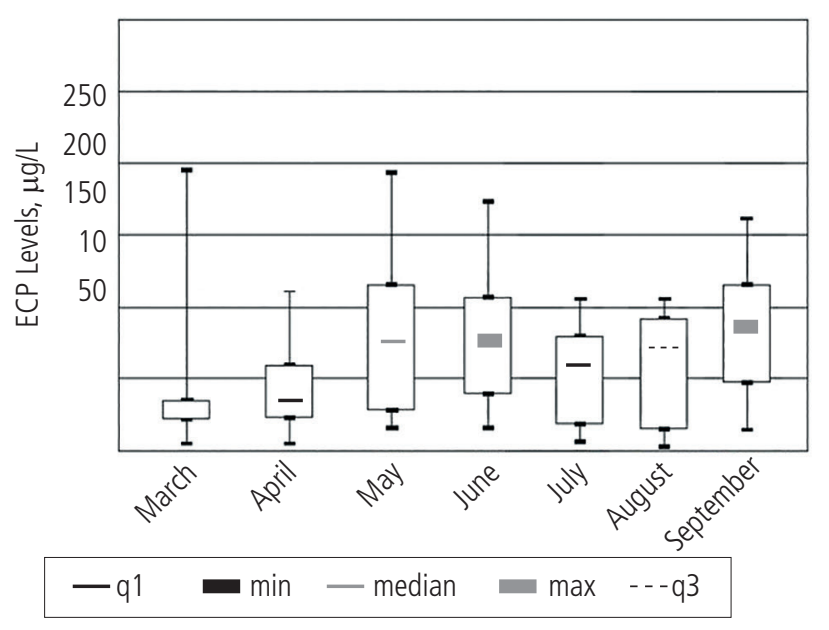

B

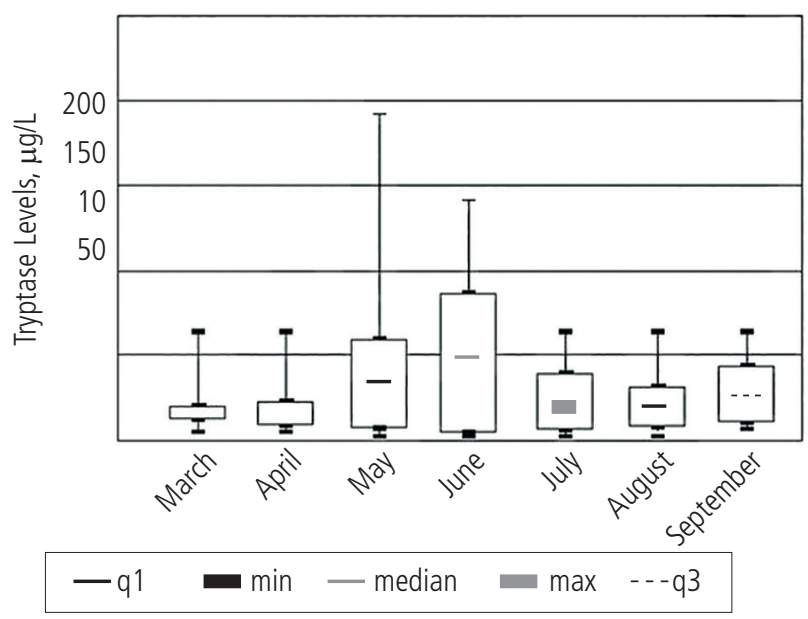

C

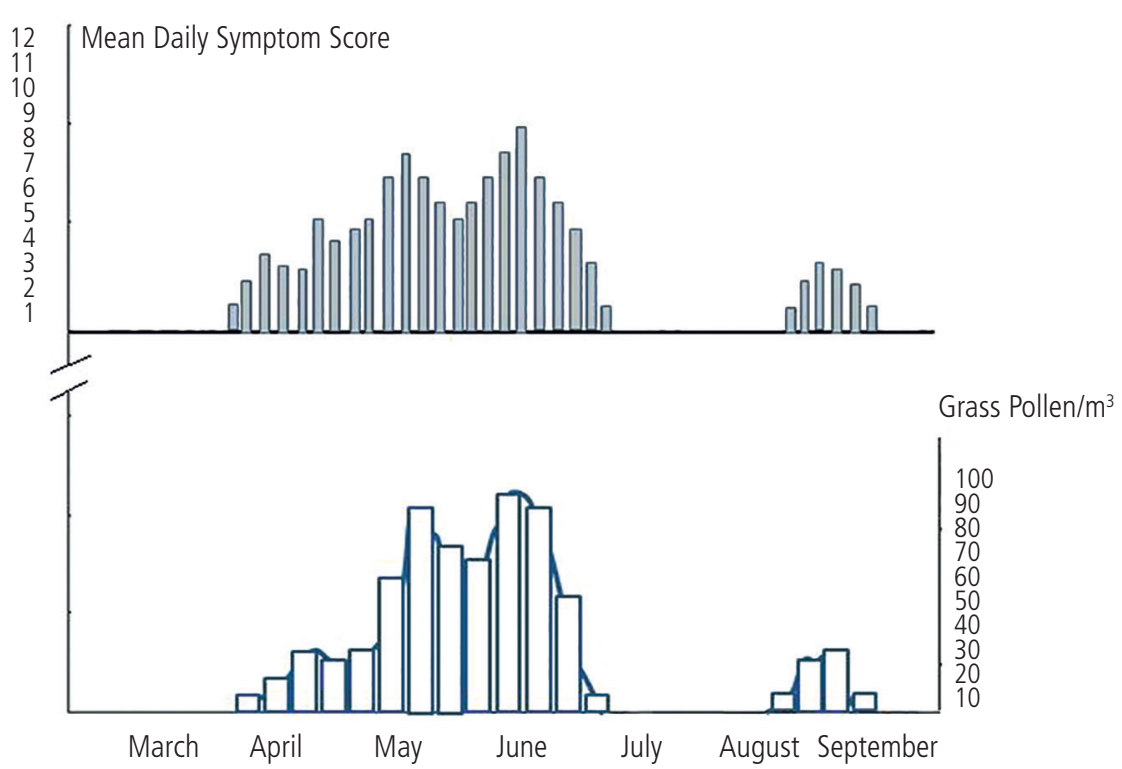

Figure. A, Eosinophil cationic protein variations during grass pollen exposure. B, Tryptase variations during grass pollen exposure. C, Rhinoconjunctivitis Total Symptom Score and pollen count.

was also observed in most patients between the end of August and the first half of September (4.23 [2.15]) (Figure, C).

We observed a clear relationship between nasal cytokine levels, grass pollen exposure, and severity of symptoms, with an increase in nasal ECP levels throughout the pollen season and greater variability in nasal tryptase levels, which were apparently more related to air concentrations and nearly mirrored pollen peaks. This different pattern of response suggests a more specific role of tryptase as a marker of allergen exposure, since it better reflects the immediate phase of reaction to the allergen. Variations in ECP were less specific and had higher values, even during periods of reduced exposure to pollen, possibly owing to the persisting late-phase activation of allergic inflammation throughout the pollen season. Both cytokines disappeared a few days after the end of the pollen season, thus reflecting the end of the inflammatory stimulus.
Our data suggest that evaluation of nasal cytokines is useful when attempting to establish a correlation between exposure and sensitizing pollens and symptoms in a pediatric population. This approach could also prove useful in polysensitized patients, a relevant group of allergic children, to better define which allergens are most responsible for clinical symptoms.

\section{Funding}

The authors declare that no funding was received for the present study.

\section{Conflicts of Interest}

The authors declare that they have no conflicts of interest. 


\section{References}

1. Bousquet J, Khaltaev N, Cruz AA, Denburg J, Fokkens WJ, Togias A, Zuberbier T, Baena-Cagnani CE, Canonica GW, van Weel C, Agache I, Ait-Khaled N, Bachert C, Blaiss MS, Bonini $S$, Boulet LP, Bousquet PJ, Camargos P, Carlsen KH, Chen Y, Custovic A, Dahl R, Demoly P, Douagui H, Durham SR, van Wijk RG, Kalayci O, Kaliner MA, Kim YY, Kowalski ML, Kuna P, Le LT, Lemiere C, Li J, Lockey RF, Mavale-Manuel S, Meltzer EO, Mohammad Y, Mullol J, Naclerio R, O'Hehir RE, Ohta K, Ouedraogo S, Palkonen S, Papadopoulos N, Passalacqua G, Pawankar R, Popov TA, Rabe KF, Rosado-Pinto J, Scadding GK, Simons FE, Toskala E, Valovirta E, van Cauwenberge P, Wang DY, Wickman M, Yawn BP, Yorgancioglu A, Yusuf OM, Zar H, Annesi-Maesano I, Bateman ED, Ben Kheder A, Boakye DA, Bouchard J, Burney P, Busse WW, Chan-Yeung M, Chavannes $\mathrm{NH}$, Chuchalin A, Dolen WK, Emuzyte R, Grouse L, Humbert M, Jackson C, Johnston SL, Keith PK, Kemp JP, Klossek JM, Larenas-Linnemann D, Lipworth B, Malo JL, Marshall GD, Naspitz C, Nekam K, Niggemann B, Nizankowska-Mogilnicka E, Okamoto Y, Orru MP, Potter P, Price D, Stoloff SW, Vandenplas O, Viegi G, Williams D; World Health Organization; GA(2)LEN; AllerGen. Allergic rhinitis and its impact on asthma (ARIA) 2008 update (in collaboration with the world health organization, GA2LEN and AllerGen). Allergy. 2008 Apr;63 Suppl 86:8-160. doi: 10.1111/j.1398-9995.2007.01620.x.

2. Esteban CA, Klein RB, Kopel SJ, McQuaid EL, Fritz GK, Seifer R, York D, Golova N, Jandasek B, Koinis-Mitchell D. Underdiagnosed and Undertreated Allergic Rhinitis in Urban School-Aged Children with Asthma. Pediatr Allergy Immunol Pulmonol. 2014 Jun 1;27(2):75-81.

3. Gelardi M, Ciprandi G, Buttafava $S$, Quaranta $N$, Squeo V, Incorvaia C, Frati F; Italian Parietaria Study Group. Nasal inflammation in Parietaria-allergic patients is associated with pollen exposure. I Investig Allergol Clin Immunol. 2014;24(5):352-3.

4. Serrano CD, Valero A, Bartra J, Roca-Ferrer J, Muñoz-Cano R, Sánchez-López J, Mullol J, Picado C. Nasal and bronchial inflammation after nasal allergen challenge: assessment using noninvasive methods. I Investig Allergol Clin Immunol. 2012;22(5):351-6.

5. Tworek D, Kuna P. Nasal Nitric Oxide Measurements in the Assessment of Nasal Allergen Challenge. J Investig Allergol Clin Immunol 2012;22(2):102-8.

6. Rondón C, Fernandez J, Canto G, Blanca M. Local Allergic Rhinitis: Concept, Clinical Manifestations, and Diagnostic Approach. J Investig Allergol Clin Immunol. 2010;20(5):36471.

D Manuscript received December 21, 2016; accepted for publication April 6, 2017.

Giuseppe Di Cara Università degli Studi di Perugia Dipartimento di Scienze Chirurgiche e Biomediche Piazza Lucio Severi 1 06123 Perugia - Italy E-mail: giu.dicara@gmail.com

\section{Identification of a Lipid Transfer Protein as a New Allergen From Morus alba Pollen}

El-Qutob D ${ }^{1}$, Bartolome $\mathrm{B}^{2}$, Cuesta $\mathrm{J}^{3}$, Mir A ${ }^{4 *}$, Alberola $\mathrm{A}^{5 *}$, Pastor-Vargas $\mathrm{C}^{6}$

${ }^{1}$ Unit of Allergy, University Hospital of La Plana, Vila-Real, Spain ${ }^{2} R \& D$ Department, Roxall, Bilbao, Spain

${ }^{3}$ Allergy Service, Instituto de Investigaciones Sanitarias Fundación Jiménez Díaz, UAM, Madrid, Spain

${ }^{4}$ Department of Medicine of the Faculty of Medicine of the University of Valencia, Valencia, Spain

${ }^{5}$ Department of Physiology of the Faculty of Medicine of the University of Valencia, Valencia, Spain

${ }^{6}$ Department of Immunology, Instituto de Investigaciones Sanitarias Fundación Jiménez Díaz, UAM, Madrid, Spain

*Both authors contributed equally to this manuscript.

J Investig Allergol Clin Immunol 2017; Vol. 27(4): 263-265 doi: $10.18176 /$ jiaci.0162

Key words: Morus alba pollen. Nonspecific lipid transfer protein. Profilin. Polysensitization.

Palabras clave: Polen de Morus alba. Proteína transferidora de lípidos no-específica. Profilina. Polisensibilización.

Pollen allergy has a significant clinical impact in Europe [1], and the prevalence of allergic rhinitis induced by pollen has been increasing in recent years [2].

Mulberry (Morus alba) pollen is one of the most allergenic pollens within the Moraceae family in Spain [3], and crossreactivity between allergens from different species of the genus Morus, and even between the members of the Moraceae family, including paper mulberry (Broussonetia papyrifera), breadfruit (Artocarpus altilis), Ficus species (eg, Ficus elastica), and jackfruit (Artocarpus heterophyllus) [4], is well known.

Despite the presence of $M$ alba pollen in the air and sensitized patients presenting positive results in skin prick tests (SPT) and/or determinations of serum specific IgE to mulberry pollen extract, the clinical relevance of sensitivity to the allergen is unknown. To date, 3 allergens have been identified in fruits from the Moraceae family, namely, Mor a 1 (member of the Bet $\mathrm{v}$ 1-like family), Mor a 4 (profilin) from white mulberry (Malba fruit), and Mor $\mathrm{n} 3$ (nonspecific lipid transfer protein [nsLTP]) from black mulberry (Morus nigra). All 3 belong to different panallergen groups.

The aim of this study was to evaluate the allergenic components of mulberry pollen extract and thus identify new allergens.

The study population comprised 45 patients sensitized to $M$ alba pollen (30 women and 15 men; mean [SD] age, 33.72 [13.42] years) who met the following criteria: (1) seasonal rhinitis and/or bronchial asthma from February to April; (2) age $>18$ years; (3) a positive SPT result to $M$ alba pollen and/or specific IgE values $>0.35 \mathrm{kU}_{\mathrm{A}} / \mathrm{L}$ to this pollen measured by the ImmunoCAP System (Thermo Fisher 
Scientific); (4) a positive result in a conjunctival provocation test with different concentrations of $M$ alba pollen extract; and (5) no previous treatment with specific immunotherapy. The protocol was approved by the Ethics Committee of the University of Valencia, Valencia, Spain, and patients included in the study provided their informed consent.

$M$ alba pollen was delipidized before being extracted by magnetic stirring under shaking in $50 \mathrm{mM}$ phosphate-buffered saline ( $\mathrm{pH} \mathrm{7.5)} \mathrm{for} 16$ hours at $4^{\circ} \mathrm{C}$. After centrifugation, the supernatant was dialyzed against distilled water. The dialyzed extract was filtered through a $0.22-\mu \mathrm{m}$-pore diameter membrane and freeze-dried. The extract was diluted in glycerinated phenol saline solution at a concentration of $5 \mathrm{mg} / \mathrm{mL}$, and SPTs were performed following European guidelines [5].

SDS-PAGE was performed with $12.5 \%$ acrylamide following Laemmli [6] and with $16.5 \%$ acrylamide and tristricine buffer as described by Schägger and von Jagow [7]. Immunoblotting and identification of proteins by tandem mass spectrometry were performed as previously described [8].

SDS-PAGE (16.5\% tricine) with $M$ alba pollen extract after Coomassie Blue staining revealed 3 small proteins with molecular masses of $10 \mathrm{kDa}, 8.5 \mathrm{kDa}$, and $7 \mathrm{kDa}$ (Figure). SDS-PAGE immunoblotting (16.5\% tricine) with $M$ alba pollen extract and patients' sera revealed a double IgE-reactive band of $14-15 \mathrm{kDa}$ in $21.8 \%$ of the sera and 3 low-molecularweight bands $(<14 \mathrm{kDa})$ in $87.5 \%$ of the sera. Other bands with lower frequencies were also observed (Figure). An immunoblotting-inhibition assay (12.5\% acrylamide) was carried out with patient sera using Malba pollen extract in the solid phase and various purified pollen profilins as inhibitors: total inhibition of IgE binding on the 14-15-kDa double band was observed for all pollen profilins. These results indicated that this double band was the profilin from $M$ alba pollen (results not shown). Mass spectrometry revealed 3 IgE-binding bands smaller than $14 \mathrm{kDa}$ : an nsLTP $(10 \mathrm{kDa})$, a ubiquitin- like protein $(8 \mathrm{kDa})$, and a cystatin-like protein $(7 \mathrm{kDa})$. An immunoblotting-inhibition assay ( $12.5 \%$ acrylamide) with $M$ alba pollen extract in the solid phase and using a patient's serum (the same serum used in Figure, lane 8) was carried out with pollen extracts (grass and olive), Pru p 3 (nsLTP from peach), and Par j 1 + Par j 2 (nsLTP from Parietaria judaica pollen) as inhibitors. Total inhibition of IgE binding on the 14-15-kDa-double band (profilin) and on the nsLTP-10 protein was observed for both pollens, whereas the Par j $1+\operatorname{Par} \mathrm{j} 2$ sample only inhibited IgE-binding to the nsLTP-10 protein. No inhibition was observed when the Pru p 3 sample was used as an inhibitor (Figure). An immunoblotting-inhibition assay (12.5\% acrylamide) showed that pollens from $P$ judaica and Olea europaea were also able to inhibit IgE binding to the ubiquitin-like protein and the cystatin-like protein (results not shown).

No allergens have been identified from $M$ alba pollen extract to date, although its fruit has yielded 2 proteins, namely, Mor a 1 (Bet v 1-like family) and Mor a 4 (profilin). We successfully identified the $M$ alba pollen extract profilin as a double band of $14-15 \mathrm{kDa}$ that appeared in $21.8 \%$ of patients' sera. Two previous studies detected 2 unidentified IgE-reactive proteins of $9 \mathrm{kDa}$ [9] and $10 \mathrm{kDa}$ [10] in M alba pollen extract. In our study, the identification of protein bands by mass spectrometry recognized 3 new allergens $<14 \mathrm{kDa}$ : a 10-kDa LTP (nsLTP-10), an 8-kDa ubiquitin-like protein, and a 7-kDa cystatin-like protein. Furthermore, immunoblottinginhibition analysis revealed the existence of cross-reactivity between nsLTP-10 and Par j 1+Par j 2, whereas no crossreactivity was detected between nsLTP-10 and Pru $\mathrm{p} 3$. The proteins that cross-reacted with the ubiquitin-like protein and the cystatin-like protein are most likely present in pollens from $P$ judaica and $O$ europaea, as can be deduced from the immunoblotting-inhibition results.

$M$ alba pollen is an allergenic source with several IgE binding components. We confirmed the significance of profilin

A
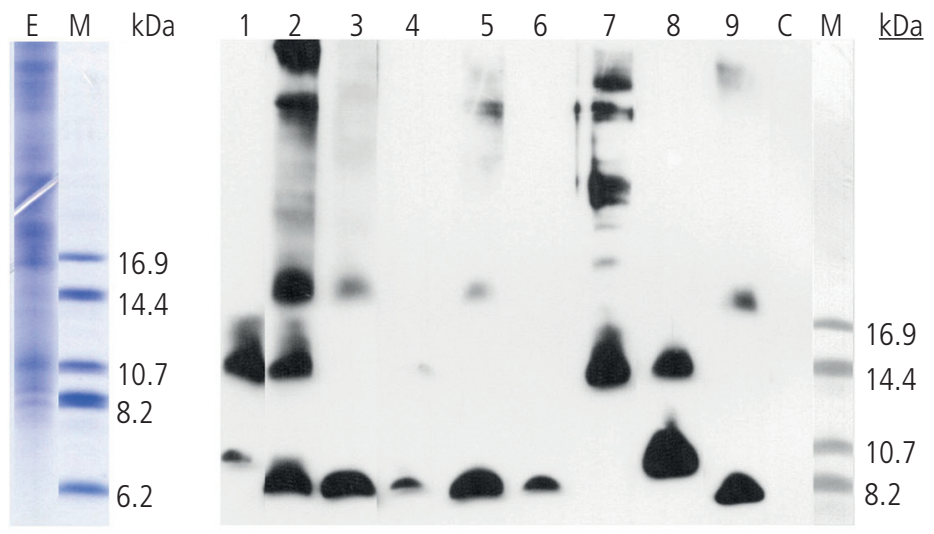

B

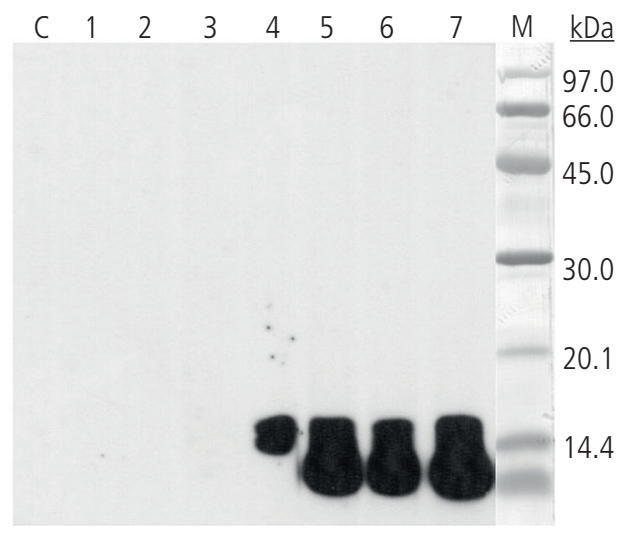

Figure. A, SDS-PAGE Coomassie Blue staining and immunoblotting ( $16.5 \%$ acrylamide-tricine buffer) with patients' sera. Lane $E$, extract from $M$ alba pollen; lanes 1-9, patients' sera; lane C, control serum (pool of sera from nonatopic individual); lane M, molecular mass standard. B, Immunoblottinginhibition (12.5\% acrylamide) with $M$ alba pollen in the solid phase and using the same serum assayed in lane 8 (Panel A). Lanes 1-7, patient serum previously incubated with Morus alba pollen extract (lane 1), with Parietaria judaica pollen extract (lane 2), with Olea europaea pollen extract (lane 3), with Par j 1+Par j 2 (lane 4), with Pru 33 (lane 5), with lamb extract (lane 6), and with bovine serum albumin (lane 7). 
sensitization in patients allergic to $M$ alba pollen extract and cross-reactivity with other pollen profilins from unrelated plant families. Further studies are needed to determine the amino acid sequence of these allergens.

\section{Acknowledgments}

The proteomic analysis was performed in the Proteomics Unit of Complutense University of Madrid, which belongs to ProteoRed, PRB2-ISCIII. The Unit is supported by grant PT13/0001.

\section{Funding}

The authors declare that no funding was received for the present study.

\section{Conflicts of Interest}

The authors declare that they have no conflicts of interest.
9. Ayuso R, Polo F, Crimi N, Palermo B, Mistretta A, Carreira J. Cross-reactivity between Morus alba and Parietaria judaica pollen allergens. Folia Allergol (Roma). 1990;37:25-33.

10. Micheal $S$, Wangorsch A, Wolfheimer $S$, Foetisch $K$, Minhas $\mathrm{K}$, Scheurer $\mathrm{S}$, Ahmed A. Immunoglobulin $\mathrm{E}$ reactivity and allergenic potency of Morus papyrifera (paper mulberry) pollen. J Investig Allergol Clin Immunol. 2013;23(3):168-75.

Manuscript received March 27, 2017; accepted for publication April 10, 2017.

David El-Qutob

Unit of Allergy of University Hospital of La Plana, Vila-Real Carretera Vila-Real-Burriana Km. 0.5 12540 Vila-Real (Castellon), Spain E-mail: elqutob@comv.es

\section{References}

1. D'Amato G, Cecchi L, Bonini S, Nunes C, Annesi-Maesano I, Behrendt H, Liccardi G, Popov T, van Cauwenberge P. Allergenic pollen and pollen allergy in Europe. Allergy. 2007 Sep;62(9):976-90.

2. Linneberg A, Dam Petersen K, Hahn-Pedersen J, Hammerby E, Serup-Hansen N, Boxall N. Burden of allergic respiratory disease: a systematic review. Clin Mol Allergy. 2016;14:12.

3. Subiza J, Jerez M, Jimenez JA, Narganes MJ, Cabrera M, Varela S, Subiza E. Allergenic pollen pollinosis in Madrid. J Allergy Clin Immunol. 1995 Jul;96(1):15-23.

4. Yman L. Botanical relations and immuno-logical crossreactions in pollen allergy. 2nd ed. Uppsala. Sweden: Pharmacia Diagnostics AB; 1982.

5. Bousquet J, Heinzerling L, Bachert C, Papadopoulos NG, Bousquet PJ, Burney PG, Canonica GW, Carlsen KH, Cox L, Haahtela T, Lodrup Carlsen KC, Price D, Samolinski B, Simons FE, Wickman M, Annesi-Maesano I, Baena-Cagnani $C E_{1}$ Bergmann KC, Bindslev-Jensen C, Casale TB, Chiriac A, Cruz AA, Dubakiene R, Durham SR, Fokkens WJ, Gerth-van-Wijk R, Kalayci O, Kowalski ML, Mari A, Mullol J, Nazamova-Baranova L, O'Hehir RE, Ohta K, Panzner P, Passalacqua G, Ring J, Rogala B, Romano A, Ryan D, Schmid-Grendelmeier P, TodoBom A, Valenta R, Woehrl S, Yusuf OM, Zuberbier T, Demoly P. Practical guide to skin prick tests in allergy to aeroallergens. Allergy. 2012 Jan;67(1):18-24.

6. Laemmli UK. Cleavage of structural proteins during the assembly of the head of bacteriophage T4. Nature. 1970 Aug 15;227(5259):680-5.

7. Schagger $H$, von Jagow $G$. Tricine-sodium dodecyl sulfatepolyacrylamide gel electrophoresis for the separation of proteins in the range from 1 to $100 \mathrm{kDa}$. Anal Biochem. 1987 Nov 1;166(2):368-79.

8. Pastor C, Cuesta-Herranz J, Cases B, Perez-Gordo M, Figueredo $E$, de las Heras M, Vivanco F. Identification of major allergens in watermelon. Int Arch Allergy Immunol. 2009;149(4):291-8. 


\section{Eosinophilic Esophagitis After Egg Oral Immunotherapy in an Adult With Egg-Allergy and Egg-Bird Syndrome}

\author{
García Rodríguez R, Méndez Díaz Y, Moreno Lozano L, \\ Extremera Ortega A, Gómez Torrijos E \\ Hospital General Universitario de Ciudad Real, Ciudad Real, \\ Spain
}

J Investig Allergol Clin Immunol 2017; Vol. 27(4): 266-267 doi: 10.18176/jiaci.0163

Key words: Eosinophilic esophagitis. Oral immunotherapy. Egg-bird syndrome. Adult. Dysphagia. Dual response.

Palabras clave: Esofagitis eosinofílica. Inmunoterapia oral. Síndrome ave-huevo. Adulto. Disfagia. Respuesta dual.

Egg allergy is much less common in adults than in small children. In adults, it is mostly caused by allergens in the yolk as a result of sensitization to inhaled bird allergens and is known as bird-egg syndrome [1]. In recent years, the number of reports on oral immunotherapy (OIT) in food-allergic children has been increasing [2], although no adult cases have been published. Eosinophilic esophagitis (EoE) has been diagnosed in children treated with OIT [3-4].

A 55-year-old woman was diagnosed with allergy to egg white when she was 1 year old. Since childhood, she had been exposed to chickens on a poultry farm. Despite following an egg-free diet, she presented with anaphylaxis upon eating trace amounts of egg as a hidden allergen. During adolescence, she began to experience epigastric pain when she ate any undercooked poultry meat. When she was 25 years old and

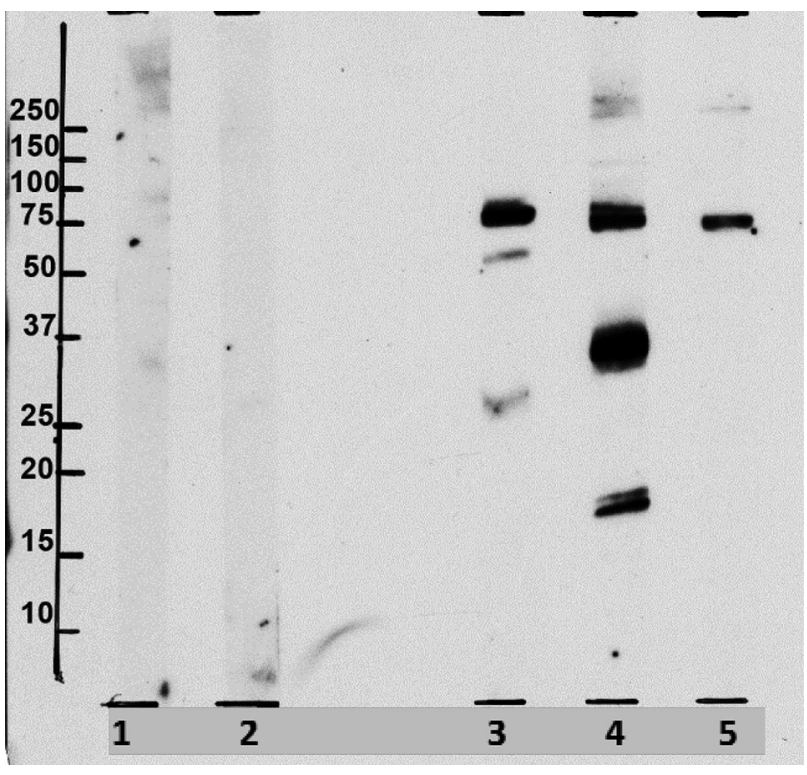

Figure. Results of SDS-PAGE immunoblotting. pregnant, she began to experience episodes of bronchospasm that worsened on direct exposure to poultry. She has since avoided exposure to birds and remains free of respiratory symptoms.

The results of skin prick tests to commercial egg white were positive $(5 \mathrm{~mm})$, egg-yolk $(3 \mathrm{~mm})$, ovalbumin $(6 \mathrm{~mm})$, ovomucoid $(7.5 \mathrm{~mm})$, and chicken meat extracts $(3.5 \mathrm{~mm})$ (ALK Abelló). Prick-by-prick tests were also positive with pasteurized egg white $(9.5 \mathrm{~mm})$ and raw egg yolk $(8.5 \mathrm{~mm})$. Specific IgE to yolk was $4.2 \mathrm{kU}_{\mathrm{A}} / \mathrm{L}$ (ImmunoCAP, Thermo Fisher), egg white $11.3 \mathrm{kU}_{\mathrm{A}} / \mathrm{L}$, ovalbumin $3.3 \mathrm{kU}_{\mathrm{A}} / \mathrm{L}$, and ovomucoid $0.62 \mathrm{kU}_{\mathrm{A}} / \mathrm{L}$.

SDS-PAGE immunoblotting (Figure) of egg yolk, egg white, and feathers with commercial nonglycerinated extracts $(1 / 20 \mathrm{wt} / \mathrm{vol})$ (ALK Abelló) was performed with the patient's serum [5]. This technique revealed a single band of approximately $70 \mathrm{kDa}$ that bound $\mathrm{IgE}$ in chicken feathers and was also present in the yolk extract. This corresponded to Gal d 5 or $\alpha$-livetin. A 31- to 37-kDa band was detected in yolk and may correspond to Gal d 6. Bands of $28 \mathrm{kDa}, 45 \mathrm{kDa}$, and $75 \mathrm{kDa}$ corresponding, respectively, to Gal d 1 (ovomucoid), Gal d 2 (ovalbumin), and Gal d 3 (ovotransferrin) were also detected in egg white. A band of approximately $20 \mathrm{kDa}$ was present in egg yolk. Its significance is uncertain, although it may correspond to vitellogenin II, a low-molecular-weight protein in egg yolk.

Single blind oral challenge tests were positive to boiled egg white and raw egg yolk.

The patient subsequently underwent rush desensitization protocols with raw egg yolk and raw egg white administered separately [6]. The raw egg yolk doses elicited digestive symptoms, although the patient could tolerate half a raw egg yolk after 5 days. Desensitization to raw egg white failed owing to frequent systemic reactions, and desensitization was subsequently undertaken with whole cooked egg (omelette); the patient finally achieved tolerance to half a cooked egg in 6 days. During the maintenance phase, she was instructed to eat half a cooked egg, although the dose had to be reduced 2 months later because of significant epigastric and abdominal pain after each dose. Since then, she has only eaten baked egg in pastries or cookies.

Three years later she complained of frequent episodes of dysphagia, knots in her neck, and heartburn upon eating any food. Even though the patient ate only baked egg and wellcooked poultry meat, an esophago-gastro-duodenoscopy with 8 biopsies ( 4 from the distal third and 4 from the mid-upper esophagus) revealed 15 eosinophils/high-power field (eos/ HPF) in the mid-upper esophagus biopsy specimen; therefore, the patient was diagnosed with EoE.

After 2 months of therapy with omeprazole ( $40 \mathrm{mg}$ bid), a new biopsy of the esophageal mucosa revealed 0 eos/HPF. She later followed a diet excluding egg and poultry for 3 months without omeprazole, and only 4 eos/HPF were detected. The patient remains asymptomatic after 1 year following the avoidance diet.

The case we report was characterized by several episodes of anaphylaxis owing to class 1 allergy to egg white that first appeared during childhood. The patient subsequently experienced digestive symptoms upon eating undercooked 
poultry and asthma after being exposed to birds (class 2 egg allergy). The patient was also sensitized to Gal d 6, which is exclusive to egg yolk. Therefore, primary sensitization to yolk was through the digestive tract. The patient was cosensitized to egg white and egg yolk allergens and cross-sensitized to egg via the inhalation of bird allergens. In their recent molecular and immunological analysis, De Silva et al [7] revealed that cosensitization to yolk allergens affected $36 \%$ of egg whiteallergic patients [7]. More studies are needed to confirm the clinical implications of this finding, that is, the importance of egg yolk in egg-allergic children.

Follow-up was similar to that of another case report of a teenager desensitized to milk [4] who developed EoE, with poor tolerance of the food doses in the maintenance phase and symptoms of esophageal dysfunction some months or years after the OIT induction phase. EoE is much more frequent after milk OIT and has seldom been described after desensitization with egg [8].

Until recently, proton pump inhibitors and exclusion diets were considered mutually exclusive [9]. Lucendo et al [10] reported on 7 patients who responded to both. We also observed a dual response, since the patient experienced clinical and histological remission, not only with high-dose omeprazole therapy, but also with the withdrawal of egg and poultry.

In conclusion, we report the first case of a patient with egg allergy and egg-bird syndrome who underwent OIT with raw egg yolk and, subsequently, with whole egg. The patient was later diagnosed with EoE, which remitted with high doses of omeprazole and an egg-free diet. At least partial tolerance can be achieved with OIT to egg in adult patients with this diagnosis. Patients undergoing OIT should be monitored in the long term to detect the possible onset of symptoms of esophageal dysfunction. Once the diagnosis of EoE has been established, both therapeutic options should be offered.

\section{Funding}

The authors declare that no funding was received for the present study.

\section{Conflicts of Interest}

The authors declare that they have no conflicts of interest.

\section{References}

1. Quirce $S$, Marañón F, Umpiérrez A, de las Heras M, FernándezCaldas E, Sastre J. Chicken serum albumin ( $G a l d 5$ ) is a partially heat-labile inhalant and food allergen implicated in the birdegg syndrome. Allergy. 2001;56:754-62.

2. Ibáñez MD, Escudero C, Sánchez-García S, Rodríguez del Río P. Comprehensi-ve Review of Current Knowledge on Egg Oral Immunotherapy, J Investig Allergol Clin Immunol. 2015;25:316-28.

3. Sánchez-García S, Rodríguez Del Río P, Escudero C, MartínezGómez MJ, Ibá-ñez MD. Possible eosinophilic esophagitis induced by milk oral immunotherapy. J Allergy Clin Immunol. 2012;129:1155-7.

4. García Rodríguez C, Gómez Torrijos E, De la Roca Pinzón F, et al. Dysphagia in a Boy Treated With Oral Immunotherapy for Cow's Milk Allergy. J Investig Allergol Clin Immunol. 2014; 24:363-5.

5. Sánchez-Madrid F, Morago G, Corbi AL, Carreira J. Monoclonal antibodies to three distinct epitopes on human $\lg \mathrm{E}$ : their use for determination of allergen-specific IgE. J Immunol Methods. 1984;73:367-78.

6. García Rodriguez R, Urra JM, Feo-Brito F, Galindo PA, Borja J, Gomez E, Lara P, Guerra F. Oral rush desensitization to egg: efficacy and safety. Clin Exp Allergy. 2011;41:1289-96.

7. De Silva C, Dhanapala P, Doran T, Tang MLK, Suphioglu C. Molecular and im-munological analysis of hen's egg yolk allergens with a focus on YGP42 (Gal d 6). Molecular Immunology. 2016;71:152-60.

8. Ridolo E, De Angelis GL, Dallaglio P. Eosinophilic esophagitis after specific oral tolerance induction for egg protein. Ann Allergy Asthma Immunol. 2011;106:73-4.

9. González-Cervera J, Lucendo AJ. Eosinophilic Esophagitis: An Evidence-Based Approach to Therapy. J Investig Allergol Clin Immunol. 2016;26:8-18.

10. Lucendo AJ, Arias A, González-Cervera J, Olalla JM, MolinaInfante J. Dual response to dietary/topical steroid and proton pump inhibitor therapy in adult pa-tients with eosinopilic eosphagitis. J Allergy Clin Immunol. 2016;137:931-4.

- Manuscript received November 20, 2016; accepted for publication April 18, 2017.

Elisa Gomez Torrijos

Hospital General Universitario de Ciudad Real Sección de Alergologia 13005 Ciudad Real, Spain E-mail: egomezt.cr@gmail.com 


\section{Physician, Beware! Drug Fever Without Skin Rashes Can Be Caused by Minocycline}

$\mathrm{Gu} \mathrm{W}^{1}$, Shi $\mathrm{D}^{1}$, Mi N ${ }^{2}$, Pang $\mathrm{X}^{1}$, Liu $\mathrm{W}^{1}$

${ }^{1}$ Department of Dermatology, General Hospital of Air Force, Beijing, China

${ }^{2}$ Hospital of Beijing Technology and Business University, Beijing, China

J Investig Allergol Clin Immunol 2017; Vol. 27(4): 268-269 doi: 10.18176/jiaci.0164

Key words: Acne. Adverse effect. Fever. Minocycline. Treatment.

Palabras clave: Acné. Efectos adversos. Fiebre. Minociclina. Tratamiento.

Minocycline is widely prescribed for the treatment of skin and venereal disease. Although a relatively safe drug, its most common adverse effects are nausea, vomiting, dizziness, and cutaneous symptoms. Severe adverse effects of minocycline include hepatitis, systemic lupus erythematosus, and hypersensitivity syndrome [1,2]. Here, we present a case of severe adverse effects, including high fever due to oral minocycline.

A 24-year-old woman was taking minocycline at her usual dose $(100 \mathrm{mg} / \mathrm{d})$ for treatment of acne. After 6 days, she went to hospital with fever $\left(39.5^{\circ} \mathrm{C}\right)$, dizziness, chest tightness, and eye pain. She was diagnosed with a cold and treated. Minocycline was discontinued. Her fever and malaise lasted for 5 days. Three days later, she restarted minocycline as treatment for acne. High fever $\left(39.2^{\circ} \mathrm{C}\right)$ and the symptoms reported above recurred within a few hours. Given the link between fever and minocycline intake, she was referred to our department. Her blood pressure, respiratory rate, and heart rate were normal. Physical examination showed neither swelling of the throat nor enlarged lymph nodes. A more detailed physical examination revealed no rash on any part of her body. Magnetic resonance imaging of the brain and computed tomography of the chest revealed no abnormalities. Additional laboratory findings disclosed eosinophilia (white blood cell count, $7.5 \times 10^{9} / \mathrm{L}$; eosinophils, $1.2 \times 10^{9} / \mathrm{L}$ ), normal C-reactive protein level, and normal liver and kidney function. Blood culture for bacteria and testing for antihuman herpesvirus $6 \mathrm{IgG}$ were negative. Based on her history of therapy with minocycline and typical clinical presentation, she was diagnosed as having minocycline-induced drug fever. The fever and other symptoms improved significantly after discontinuation of minocycline and oral prednisolone $(30 \mathrm{mg} / \mathrm{d})$. Her clinical course is illustrated in the Figure. Application of the Spanish Pharmacovigilance System probability algorithm (modified Karch-Lasagna algorithm) revealed the causality between the adverse drug reaction and the drug to be definite $[3,4]$.

Minocycline-induced fever is rare but can be serious. Grim et al [5] reported a case of severe drug fever complicated with malaise that was overlooked during long-term therapy with minocycline [5]. In the case we report, the patient was initially

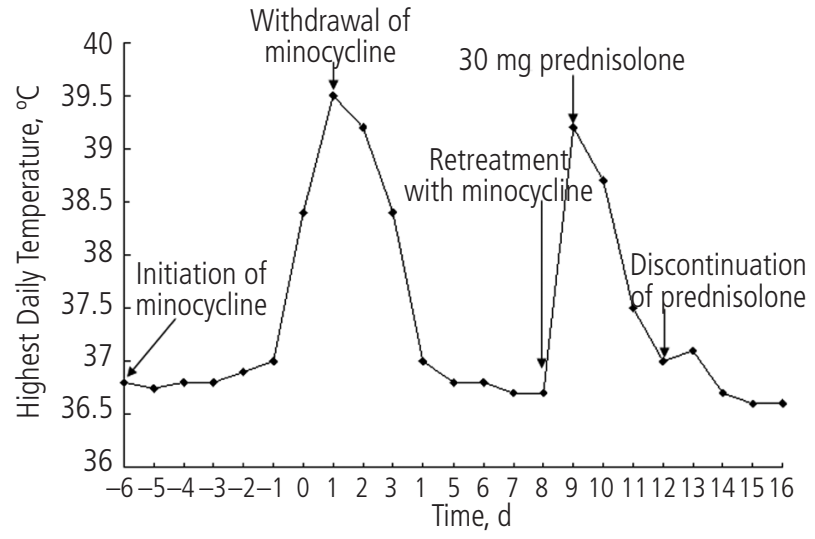

Figure. Highest daily temperature during the clinical course. The fever deteriorated during therapy with minocycline and improved when the drug was discontinued.

diagnosed as having a cold. Discontinuation of minocycline led to improvement of symptoms. Reinitiation of treatmentwhich acted as an oral challenge test-induced fever again and thus confirmed the diagnosis. The adverse effects of minocycline vary from patient to patient and include dizziness, nausea, and skin rashes such as urticaria [6]. The patient presented fever complicated with dizziness, chest tightness, and eye pain. However, in contrast with previous cases, she did not present skin rash. The diagnosis of drug fever is often difficult, and a careful review of the clinical presentation and medication history can confirm the diagnosis. Although this patient had severe symptoms, the diagnostic criteria for drug reaction with eosinophilia and systemic symptoms were not fulfilled because of the absence of skin rash and other systemic features $[7,8]$.

As well as illustrating a rare adverse reaction to minocycline, our report emphasizes the need for physicians and dermatologists to be on the alert for the unusual druginduced fever, especially in patients without apparent skin rashes. Notification of adverse drug reactions is mandatory for all healthcare professionals and pharmaceutical companies in many countries. For example, the Spanish Pharmacovigilance Service (RDL 1/2015, 24 July) established a system to monitor the safety of authorized medicinal products and detect any change to their risk-benefit balance [9].

\section{Funding}

The authors declare that no funding was received for the present study.

\section{Conflicts of Interest}

The authors declare that they have no conflicts of interest.

\section{References}

1. Crosson J, Stillman MT. Minocycline-related lupus erythematosus with associated liver disease. I Am Acad Dermatol. 1997;36:867-8. 
2. Talsania N, O'Toole EA. Severe hypersensitivity reaction to minocycline in association with lymphomatoid papulosis. Clin Exp Dermatol. 2009;34:e397-8.

3. Naranjo CA, Busto U, Sellers EM, Sandor P, Ruiz I, Roberts EA, Janecek E, Domecq C, Greenblatt DJ. A method for estimating the probability of adverse drug reactions. Clin Pharmacol Ther. 1981;30:239-45.

4. Aguirre C, Garcia M. Causality assessment in reports on adverse drug reactions. Algorithm of Spanish pharmacovigilance system. Med Clin (Barc). 2016;147:461-4.

5. Grim SA, Romanelli F, Jennings PR, Ofotokun I. Late-onset drug fever associated with minocycline: case report and review of the literature. Pharmacotherapy. 2003;23:1659-62.

6. Jang JW, Bae YJ, Kim YG, Jin YJ, Park KS, Cho YS, Moon HB, Kim TB. A case of anaphylaxis to oral minocycline. J Korean Med Sci. 2010:25:1231-3.

7. Radu C, Barnig C, de Blay F. Rivaroxaban-Induced Drug Reaction With Eosinophilia and Systemic Symptoms. J Investig Allergol Clin Immunol. 2016;26:124-6.

8. Arruti N, Villarreal O, Bernedo N, Audicana MT, Velasco M, Uriel O, Martinez A, Bellon T. Positive Allergy Study (Intradermal, Patch, and Lymphocyte Transformation Tests) in a Case of Isoniazid-Induced DRESS. J Investig Allergol Clin Immunol. 2016;26:119-20.

9. Life Sciences Global Guide 2016/17. Medicinal product regulation and product liability in Spain: overview. March 2016. Available from: http://uk.practicallaw.com/8-500-4409 2016.

1. Manuscript received December 14, 2016; accepted for publication April 19, 2017

Wei Liu

No. 30 Fucheng Road Haidian District Beijing 100142, China

\section{Donkey's Milk Is Well Accepted and Tolerated by Infants With Cow's Milk Food Protein-Induced Enterocolitis Syndrome: A Preliminary Study}

Mori $F^{1}$, Sarti L ${ }^{1}$, Barni $\mathrm{S}^{1}$, Pucci N ${ }^{1}$, Belli F², Stagi $\mathrm{S}^{3}$, Novembre E ${ }^{1}$ Allergy Unit, Department of Pediatrics, Anna Meyer Children's University Hospital, Florence, Italy

${ }^{2}$ Nutrition Unit, Department of Pediatrics, Anna Meyer Children's University Hospital, Florence, Italy

${ }^{3}$ Department of Health Sciences, University of Florence, Anna Meyer Children's University Hospital, Florence, Italy

J Investig Allergol Clin Immunol 2017; Vol. 27(4): 269-271 doi: $10.18176 /$ jiaci.0167

Key words: Children. Cow's milk. Donkey's milk. Food-protein induced enterocolitis syndrome.

Palabras clave: Niños. Leche de vaca. Leche de burra. Síndrome de enterocolitis inducida por proteína alimentaria.

Food protein-induced enterocolitis syndrome (FPIES) is a type of non-IgE-mediated food hypersensitivity reaction that is characterized by vomiting, diarrhea, lethargy, and, in some cases, hypovolemic shock and metabolic acidosis. The diagnosis is based on the clinical history and food challenge when appropriate [1]. Cow's milk proteins (CM) and soy milk (SM) proteins are among the most common triggers of FPIES. Negative skin test and cow's milk serum specific IgE results make it possible to differentiate between FPIES and typical CM allergy.

When treating an infant with CM FPIES in the first 6-12 months of life, physicians should suggest a safe and nutritionally appropriate alternative to parents.

Donkey's milk (DM) is available in many regions of Italy. We tested tolerance to DM in 6 children with CM FPIES who were referred to our allergy unit over a 2-year period (2015-2016)

Prick-by-prick testing with CM, SM, casein-based extensively hydrolyzed formula (eHF), DM, and goat's milk was performed according to the recommendations of the European Academy of Allergy and Clinical Immunology. All 6 patients were diagnosed with CM FPIES within 6 months of age according to the criteria of Miceli Sopo et al [1]. An oral provocation test (OPT) was performed according to the protocol of Leonard and Nowak-Wegrzyn [2] in a hospital setting with emergency facilities available.

The final dose of DM and/or SM was $150-200 \mathrm{~mL}$ of the whole food, because DM contains $3.3 \mathrm{~g}$ of protein in $200 \mathrm{~mL}$.

Tolerance of SM or DM was checked within 3 months of the diagnosis of CM FPIES. DM was provided free to the infants tested, as it is very expensive in some regions of Italy.

The nutritional state of all 6 children was evaluated before feeding with DM. We recorded weight, height, and blood levels of calcium, vitamin D, and insulin-like growth factor (IGF1).

The demographic and allergy profiles of the 6 infants are summarized in the Table. Three of the 6 children had a positive 
Table. Demographic Characteristic and Allergy Profiles

\begin{tabular}{|c|c|c|c|c|c|c|c|c|c|c|c|c|c|c|}
\hline \multirow[t]{2}{*}{ No. } & \multicolumn{2}{|c|}{$\begin{array}{r}\text { Sex CM } \\
\text { FPIES }\end{array}$} & Reactions & \multirow[t]{2}{*}{$\begin{array}{c}\text { Age at } \\
\text { Diagnosis, } \\
\text { mo }\end{array}$} & \multicolumn{5}{|c|}{$\begin{array}{l}\text { Allergy tests } \\
(\mathrm{P}+\mathrm{P}, \mathrm{mm})\end{array}$} & \multirow[t]{2}{*}{$\begin{array}{c}\text { Serum } \\
\text { specific } \\
\operatorname{IgE}, \mathrm{kU}_{\mathrm{A}} / \mathrm{L}\end{array}$} & \multirow[t]{2}{*}{$\begin{array}{l}\text { CM } \\
\text { OPT }\end{array}$} & \multirow[t]{2}{*}{$\begin{array}{l}\text { Soy } \\
\text { OPT }\end{array}$} & \multirow[t]{2}{*}{$\begin{array}{l}\text { eHF } \\
\text { OPT }\end{array}$} & \multirow[t]{2}{*}{$\begin{array}{c}\text { Donkey } \\
\text { OPT }\end{array}$} \\
\hline & & $\begin{array}{l}\text { Age, } \\
\text { mo }\end{array}$ & $\begin{array}{c}\text { Clinical } \\
\text { characteristics }\end{array}$ & & $\mathrm{eHF}$ & $\mathrm{CM}$ & GM & $\mathrm{SM}$ & $\mathrm{DM}$ & & & & & \\
\hline 1 & $\mathrm{~F}$ & 1.5 & $\begin{array}{l}\text { Repetitive } \\
\text { vomiting after } \\
60 \text { minutes } \\
\text { Repetitive } \\
\text { vomiting after } \\
60 \text { minutes }\end{array}$ & 3 & 0 & 0 & 0 & 0 & 0 & NP & $\begin{array}{c}\text { Positive } \\
\text { (vomiting, pallor, } \\
\text { hypotonia after } \\
60 \text { minutes; } \\
\text { intravenous } \\
\text { ondansetron } \\
\text { and fluids) }\end{array}$ & $\mathrm{T}$ & NA & $\mathrm{T}$ \\
\hline \multirow[t]{3}{*}{2} & $\mathrm{~F}$ & 2 & $\begin{array}{l}\text { Repetitive vomiting } \\
\text { and lethargy } \\
\text { (after } 1.5-2 \text { hours) }\end{array}$ & 3 & 0 & 0 & 0 & 0 & 0 & NP & NP & $\mathrm{T}$ & $\mathrm{T}$ & $\mathrm{T}$ \\
\hline & & 2.5 & $\begin{array}{c}\text { Repetitive } \\
\text { vomiting and } \\
\text { lethargy } \\
\text { (after } 1.5-2 \text { hours) }\end{array}$ & & & & & & & & & & & \\
\hline & & 3 & $\begin{array}{l}\text { Repetitive vomiting } \\
\text { and lethargy } \\
\text { (after } 1.5-2 \text { hours) }\end{array}$ & & & & & & & & & & & \\
\hline 3 & $\mathrm{~F}$ & 3 & $\begin{array}{l}5 \text { episodes of } \\
\text { repetitive vomiting } \\
\text { after } 90 \text { minutes }\end{array}$ & 3 & 0 & 5 & 0 & 0 & 0 & 10 & $\mathrm{NP}$ & $\mathrm{T}$ & $\mathrm{T}$ & $\mathrm{T}$ \\
\hline 4 & $\mathrm{~F}$ & 6 & $\begin{array}{c}\text { Repetitive vomiting } \\
\text { and lethargy after } \\
90 \text { minutes }\end{array}$ & 6 & 0 & 0 & 0 & 0 & 0 & NP & $\begin{array}{l}\text { ED } \\
\text { (intravenous } \\
\text { ondansetron } \\
\text { and fluids) }\end{array}$ & $\mathrm{T}$ & NT & $\mathrm{T}$ \\
\hline 5 & $\mathrm{~F}$ & 4 & $\begin{array}{l}\text { Repetitive vomiting } \\
\text { and lethargy } \\
\text { after } 2 \text { hours }\end{array}$ & 5 & 0 & 0 & 0 & 0 & 0 & 0 & $\begin{array}{c}\text { Positive } \\
\text { (vomiting after } \\
120 \text { minutes) }\end{array}$ & NT & NA & $\mathrm{T}$ \\
\hline 6 & $\mathrm{M}$ & 2.5 & $\begin{array}{l}\text { Repetitive vomiting } \\
\text { and lethargy after } \\
90-120 \text { minutes }\end{array}$ & 6 & NT & 0 & 0 & 0 & 0 & $\mathrm{NP}$ & $\mathrm{NP}$ & NT & NA & $\mathrm{T}$ \\
\hline
\end{tabular}

Abbreviations: CM, cow's milk; DM, donkey's milk; ED, emergency department; eHF, extensively hydrolyzed formula; F, female; GM, goat's milk; M, male; NA, not accepted; NP, not performed; NT, not tested; OPT, oral provocation test; P+P, prick by prick; SM, soy milk; T, tolerated.

family history of atopy, but none of the infants had atopic dermatitis. Two out of the 6 children were diagnosed by oral provocation test with $\mathrm{CM}$ proteins, and 1 of the 6 children was diagnosed during an acute FPIES episode. The diagnosis was confirmed based on the clinical history (ie, $\geq 2$ typical episodes) in 3 of the 6 children [1]. One of the 6 children had CM-specific IgE (atypical FPIES). However, even when that child was excluded, all of the remaining 5 children with CMinduced enterocolitis syndrome tolerated DM.

Most of the children also tolerated SM (4 out of 6), and eHF was a safe but unpalatable alternative ( 3 out of 6 children would not consume the eHF because of its taste). The mothers of the first 3 children (Table), who were diagnosed as having CM FPIES at 3 months of age, were advised to breastfeed their babies until 5 to 6 months of age. All 6 children reached the 6-month follow-up period (from 6 months of age until 12 months), maintained the same weight and height percentiles, and had no deficit in calcium, vitamin D, or IGF1 (data not shown).

We found that DM was a safe and well-tolerated alternative in 6 children with CM FPIES. Moreover, it is nutritionally adequate in weaned infants. As for SM, it has been reported that $65 \%$ [3], 43.5\% [4], and 37\% [5] of children with CM FPIES 
also reacted to SM. The authors consequently encouraged breastfeeding and recommended using casein-based eHF or an amino acid formula. Reactions to SM should be assessed in a hospital setting.

Our findings differ from those of Katz et al [6], who reported that of 44 Israeli children with FPIES triggered by CM, none reacted to other foods, including SM. Mehr et al [7] reported that of 35 Australian children, none reacted to either SM or CM.

In a multicenter trial conducted by Sopo et al [8], the authors showed that, once again, none of the children reacted to $\mathrm{CM}$ and SM. The authors of the 3 previously mentioned studies [6-8] recommended $\mathrm{SM}$ as a valid alternative in children with CM FPIES. Moreover, SM-based formulas have moderate palatability and provide appropriate nutrition. The present study also showed that 4 out of 5 patients with CM FPIES tolerated SM. According to our results and taking into account that DM does not have any nutritional advantage over SM, we could only assume that DM is useful as an additional alternative in children with CM FPIES who do not tolerate SM or eHF.

SM-based formulas are contraindicated for the treatment of infants with some forms of non-IgE-associated gastrointestinal CM hypersensitivity. In such cases, DM should be recommended. DM is also favored because of its pleasant taste and the positive feedback from patients who have tried it.

Consensus guidelines from the World Allergy Organization recommend the use of $\mathrm{eHF}$, which has good nutritional value but is expensive and unpalatable.

The literature contains few studies on other mammalian milk products. Thus far, cross-reactivity between foods has not yet been described in FPIES.

Shek et al [9] reported casein to be the major allergen in FPIES. Consequently, goat's milk or sheep's milk should be avoided because of the high degree of homology with CM and its poor nutritional properties [9].

Among mammalian milk products, DM shows little crossreactivity with $\mathrm{CM}$.

The nutritional composition of DM is similar to that of human milk. Its high lactose content not only makes DM palatable, but also stimulates intestinal absorption of calcium. Moreover, Monti et al [10] found that DM contains levels of casein and whey proteins similar to those in human milk, as well as a high concentration of essential amino acids. However, the low fat content of DM means that it has a low energetic value [10], thus limiting its use for infants on an exclusively milk-based diet. The authors found that DM was tolerated by 13 children with non-IgE-mediated gastrointestinal symptoms.

This is the first report to show that DM is well accepted and tolerated by children diagnosed with CM FPIES. However, our sample (6 infants) was too small to enable us to recommend $\mathrm{DM}$ as a substitute for CM. Despite major concerns regarding the nutritional properties of DM in the first 6 months of life, our results indicate that it could be considered a valid alternative in weaned infants (older than 5-6 months). Well-designed clinical studies are needed to confirm our findings.

Funding

The authors declare that no funding was received for the present study.

\section{Conflicts of Interest}

The authors declare that they have no conflicts of interest.

\section{References}

1. Miceli Sopo S, Greco M, Monaco S, Tripodi S, Calvani M. Food Protein-induced enterocolitis Syndrome, from practice to theory. Expert Rev Clin Immunol. 2013;9:707-15.

2. Leonard SA, Nowak-Wegrzyn A. Food protein-induced enterocolitis syndrome: an update on natural history and review of management. Ann Allergy Asthma Immunol 2011;107:95-101.

3. Nowak-Wegrzyn A, Sampson HA, Wood RA, Sicherer SH. Food protein-induced enterocolitis syndrome caused by solid food proteins. Pediatrics. 2003;111:829-35.

4. Ruffner MA, Ruymann K, Barni S, Cianferoni A, BrownWhitehorn T, Spergel JM. Food protein-induced enterocolitis syndrome: insights from review of a large referral population. J Allergy Clin Immunol Pract. 2013;1:343-9.

5. Caubet JC, Ford LS, Sickles L, Järvinen KM, Sicherer $S H$, Sampson HA, Nowak-Węgrzyn A. Clinical features and resolution of food protein-induced enterocolitis syndrome: 10-year experience. J Allergy Clin Immunol. 2014;134:382-9.

6. Katz Y, Goldberg MR, Rajuan N, Cohen A, Leshno M. The prevalence and natural course of food protein-induced enterocolitis syndrome to cow's milk: a large-scale, prospective population-based study. J Allergy Clin Immunol. 2011;127:647-53.

7. Mehr S, Kakakios A, Frith K, Kemp AS. Food protein-induced enterocolitis syndrome: 16-year experience. Pediatrics. 2009;123:3459-e64.

8. Sopo SM, Giorgio V, Dello lacono I, Novembre E, Mori F, Onesimo R. A multicentre retrospective study of 66 Italian children with food protein-induced enterocolitis syndrome: different management for different phenotypes. Clin Exp Allergy. 2012;42:1257-65.

9. Shek LP, Bardina L, Castro R, Sampson HA, Beyer K. Humoral and cellular responses to cow milk proteins in patients with milk-induced IgE-mediated and non-lgE-mediated disorders. Allergy. 2005;60:912-9.

10. Monti G, Bertino E, Muratore MC, Coscia A, Cresi F, Silvestro $L$, Fabris C, Fortunato D, Giuffrida MG, Conti A. Efficacy of donkey's milk in treating highly problematic cow's milk allergic children: An in vivo and in vitro study. Pediatr Allergy Immunol. 2007; 18:258-64

Manuscript received September 30, 2016; accepted for publication April 28, 2017.

Simona Barni

Viale Pieraccini 24 50134 Florence

Italy

E-mail: simonabarni@hotmail.com 


\section{An Unusual Case of Contact Dermatitis Caused by a Pacemaker Implanted for Neurostimulation}

Pérez González EL, Medina Alfaro I, Iglesias Cadarso A, Boteanu C Allergy Section, Hospital Universitario Puerta de Hierro, Majadahonda, Spain

J Investig Allergol Clin Immunol 2017; Vol. 27(4): 272-273 doi: $10.18176 /$ jiaci.0168

Key words: Contact Dermatitis. Silicone allergy. Pacemaker allergy.

Palabras clave: Dermatitis de contacto. Alergia a la silicona.

Neurostimulation with pacemakers can be used to treat pain. The pacemaker generates electrical impulses that are controlled by means of an electrode signal, thus blocking nerve pain. The generator and the electrodes are coated with silicone, which exhibits negligible allergenicity, in order to prevent adverse reactions to the other materials used in the pacemaker.
We report a case of hypersensitivity to silicone and rhodium in a patient with a pacemaker implanted for neurostimulation.

A 42-year-old man was referred to our allergy department with pain at the insertion site of a pacemaker that began 3 months after subcutaneous implantation in the abdomen to stimulate the right obturator nerve. The pain was not accompanied by inflammatory signs or skin lesions, although it worsened after 9 months. A blood test revealed elevated C-reactive protein and neutrophilia. Cultures taken from the area were negative, and computed tomography and ultrasound scans of the soft tissue were normal. However, the pacemaker was removed owing to possible infection, and empiric antibiotic treatment was started. A new pacemaker was inserted, and 1 month later the patient presented severe pain, erythema, and surface heat. The pacemaker was removed definitively. Assessment at our allergy department 8 days later revealed that the local erythema and discomfort had resolved. The patient had no history of drug allergy or atopic or contact dermatitis and no other medical history of note.

A full work-up was performed with the T.R.U.E. test standard series (Smartpractice Denmark ApS), reagents of the pacemaker supplied by manufacturer (Medtronic), and other silicones and metals (Table).

Table. Results of Patch Testing ${ }^{a}$

$48 \mathrm{~h} \quad 96 \mathrm{~h} \quad$ Control Patient

(48 and $96 \mathrm{~h}$ )

Medtronic pacemaker components
A: Silicone medical adhesive A
B: Silicone rubber (MDX-70 peroxide cured)
C: Silicone rubber (ETR-50 platinum-cured)
D: Silicone rubber (Med 4719 platinum-cured)
E: Polysulfone (amber)
F: Polyurethane (75D)
G: Polysulfone (beige)
$\mathrm{H}$ : Polyurethane (80A)

$(+++) \quad(++)$

$(-)$

$(++)$

$(+)$

$(-)$

$(++)$

$(+)$

$(-)$

$(++)$

$(+)$

$(-)$

$(-)$

$(-)$

(-)

$(-)$

$(-)$

$(-)$

Metals, components of pacemaker and electrode

1: Parylene-coated titanium

$(-) \quad(-)$

2: Barium sulfate-filled silicone rubber

3: Titanium

$(-)$

4: Platinum-iridium

$(-) \quad(-)$

Silicones used in modeling and medical applications

5: Glazier's silicone

6: White silicone mold

7: Transparent silicone mold

8: Medical silicone (urinary catheter)

T.R.U.E. test 3 panels

$$
\begin{aligned}
& \text { Catalyzers } \\
& \text { Platinum (hexachloride) (in vaseline) } \\
& \text { Palladium (chloride) (in vaseline) } \\
& \text { Tin (metallic) (in vaseline) } \\
& \text { Rhodium (trichloride) (in vaseline) }
\end{aligned}
$$

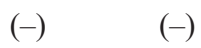

\begin{tabular}{ll}
$(-)$ & $(-)$ \\
- & - \\
- & - \\
- & - \\
++ & \\
\hline
\end{tabular}

${ }^{a}$ The components were analyzed in physiological saline solution unless otherwise indicated. 
We obtained positive results with rhodium and the 4 types of silicone used in the pacemaker, of which only 1 was rhodium-catalyzed (Silicone Medical Adhesive A).

Analysis of a biopsy specimen taken from the area affected by the application of a $2 \%$ rhodium patch confirmed contact dermatitis, which manifested as a minimal epidermal focus of spongiosis, lymphocytic exocytosis, and isolated necrotic keratinocytes. A minimal superficial perivascular lymphocytic infiltrate was also observed. Morphological changes were minimal and may be attributable to contact dermatitis.

Based on these data, we made a diagnosis of contact dermatitis induced by silicone and rhodium, although we cannot completely rule out the possibility of contamination of the platinum or silicones by rhodium.

Silicones are polymers of polysiloxane, which comprises chains of alternating silicon atoms and oxygen atoms, to which organic and inorganic groups can be added, thus providing them with various properties. Given their physicochemical characteristics, allergenicity is very low. Silicones are polymerized using catalysts such as transition metals (tin, platinum, palladium, or rhodium) and organic substances (eg, peroxide), which have known allergenicity.

Silicones are widely used in sectors such as health care, industry, transport, technology, and cosmetics, as well as in products used in the home. Cosmetics and home products are of great interest in allergy, because the increasingly frequent use of silicones means that they may be involved in hypersensitivity reactions.

Rhodium is a transition metal belonging to the platinum group that usually contaminates platinum. A scarce substance, it is used mainly as a catalyst in some platinum alloys; in its galvanized form, it is common in jewelry, electrical contacts, and mirrors. Hypersensitivity skin reactions due to rhodium are rare and occur mainly in the workplace $[5,6]$.

The few reports of adverse reactions to silicones include foreign body reaction, skin necrosis, local pain, and, even more rarely, contact dermatitis [1-4,7-9]. The most common causes of adverse reactions to pacemakers are local infections, although in the absence of fever or other signs of infection (negative cultures, no leukocytosis), the possibility of contact hypersensitivity to its components should be considered.

Although rare, hypersensitivity to silicone should be taken into account in patients with pacemakers who experience contact dermatitis.

\section{Funding}

The authors declare that no funding was received for the present study.

\section{Conflicts of Interest}

The authors declare that they have no conflicts of interest.

\section{Previous Presentations}

This study was presented as a poster at the XXIX National Congress of the Spanish Society of Allergology.

\section{References}

1. Abdallah HI, Balsara RK, O'Riordan AC. Pacemaker contact sensitivity: clinical recognition and management. Ann Thorac Surg. 1994;57:1017-8.

2. Oprea ML, Schnöring H, Sachweh JS, Ott H, Biertz J, VazquezJimenez JF. Allergy to Pacemaker Silicone Compounds: Recognition and Surgical Management. Ann Thorac Surg. 2009;87:1275-7.

3. Puri S, Dornhoffer JL, North PE. Contact dermatitis to silicone after cochlear implantation. Laryngoscope. 2005;115:1760-2.

4. Tamenishi A, Usui A, Oshima H, Ueda Y. Entirely polytetrafluoroethylene coating for pacemaker system contact dermatitis. Interact Cardiovasc Thorac Surg. 2008;7:275-7.

5. Goossens A, Cattaert N, Nemery B, Boey L, DeGraef E. Occupational allergic contact dermatitis caused by rhodium solutions. Contact Dermatitis. 2011;64:158-61.

6. Stingeni L, Brunelli L, Lisi P. Contact sensitivity to rhodium and iridium in consecutively patch tested subjects. Contact Dermatitis. 2004;51:316-7.

7. Vodiskar J, Schnoring H, Sachweh JS, Mühler E, VazquezJimenez JF. Polytetrafluoroethylene-coated pacemaker leads as surgical management of contact allergy to silicone. Ann Thorac Surg. 2014;97:328-9.

8. Dargan D, McGoldrick C, KhanK. Type IV hypersensitivity to a textured silicone breast implant. J Plast Reconst Aesthet Surg. 2012;65:969-72.

Manuscript received February 28, 2017; accepted for publication April 28, 2017.
Esther Lourdes Pérez González

Calle Manuel de Falla $N^{\circ} 1$ 28222 Majadahonda (Madrid) Spain

E-mail: lourdesspg@gmail.com 


\section{Stevens-Johnson Syndrome After Influenza Vaccine Injection}

Oda T, Sawada Y, Okada E, Yamaguchi T, Ohmori S, Haruyama $\mathrm{S}$, Yoshioka M, Nakamura M

Department of Dermatology, University of Occupational and Environmental Health, Kitakyushu City, Fukuoka, Japan

J Investig Allergol Clin Immunol 2017; Vol. 27(4): 274-275 doi: 10.18176/jiaci.0169

Key words: Stevens-Johnson syndrome. Influenza vaccine.

Palabras clave: Síndrome de Stevens-Johnson. Vacuna frente a la gripe.

Influenza vaccine is widely used for the prevention of seasonal influenza virus infection. Several cutaneous allergic reactions to influenza vaccine have been reported $[1,2]$. We report a case of Stevens-Johnson syndrome after administration of influenza vaccine.

A 75-year-old man had received influenza vaccine for prevention of seasonal influenza infection every year since 2014. He reported erythematous papules 2 days after receiving his injection in 2015. In 2016, he noticed erythema on his trunk and extremities 1 day after administration of the vaccine and developed lesions of the eye and oral mucosa 2 days later. He was referred to our department for evaluation of the skin eruption. He had taken no other medication and was not allergic to egg. Physical examination revealed annular erythema on the trunk (Figure, A) and a mucosal lesion in the oral cavity (Figure, B) and eyelids (Figure, C). The Nikolsky sign was positive. The patient had a high fever $\left(37.7^{\circ} \mathrm{C}\right)$. A skin biopsy taken from the erythema on the trunk revealed dyskeratotic keratinocytes in the epidermis and lymphocytic infiltration in the epidermis and dermis (Figure, D). Furthermore, the dermis was infiltrated by eosinophils. The laboratory examination ruled out infection by herpes simplex virus, Epstein-Barr virus, and mycoplasma. Serum antidesmograin- 1 or -3 antibody and bacterial swab culture from the skin erosion were negative. The white blood cell count was slightly elevated. We diagnosed the skin eruption as Stevens-Johnson syndrome due to influenza vaccine. The patient received oral prednisolone $(30 \mathrm{mg} / \mathrm{d})$, and the eruption resolved completely 1 month after treatment. Because we could not obtain the patient's consent for patch testing using influenza vaccine, we performed patch testing using additives in the vaccine, which included formalin and thiomersal. However, the result of patch testing with these agents was negative. Therefore, we hypothesize that the patient developed Stevens-Johnson syndrome to the influenza vaccine itself.

Cutaneous adverse events reported after influenza vaccine injection include vasculitis [1] and lichenoid drug eruptions [2]. One case of Stevens-Johnson syndrome has been reported after combination treatment with influenza vaccine and flucloxacillin [3]. However, the case we report is the first case of Stevens-Johnson syndrome after influenza vaccine monotherapy. A vaccine consists of the vaccine itself and additives. In the present case, patch testing indicated that additives such as formalin and thiomersal were not responsible for the cutaneous adverse reaction. Therefore, this patient may have experienced a hypersensitivity reaction to the seasonal influenza vaccine itself, leading to Stevens-Johnson syndrome. Because the patient first developed the skin eruption after the 2015 seasonal influenza vaccine injection, a common antigen in the 2014 and 2015 seasonal influenza vaccine could have been the causative agent. We speculated that a causative agent might be A/California/7/2009(X-179A)(H1N1)pdm09, which was a common antigen in seasonal influenza vaccine from 2014 to 2016

Additives in vaccine have been known to cause drug eruptions [4,5]. Thiomersal is a representative additive in vaccine and is used as a preservative in various presentations. It has been reported to be a possible causative agent for vaccineinduced drug eruptions [4]. The recently developed thiomersalfree influenza vaccine should prove beneficial in patients who experience hypersensitivity reaction to thiomersal.

Clinicians should bear in mind that not only the vaccine but also additives in the vaccine can cause vaccine-related drug eruption. Because influenza vaccine-induced cutaneous adverse events are relatively rare, further investigation is necessary to clarify their pathogenesis.

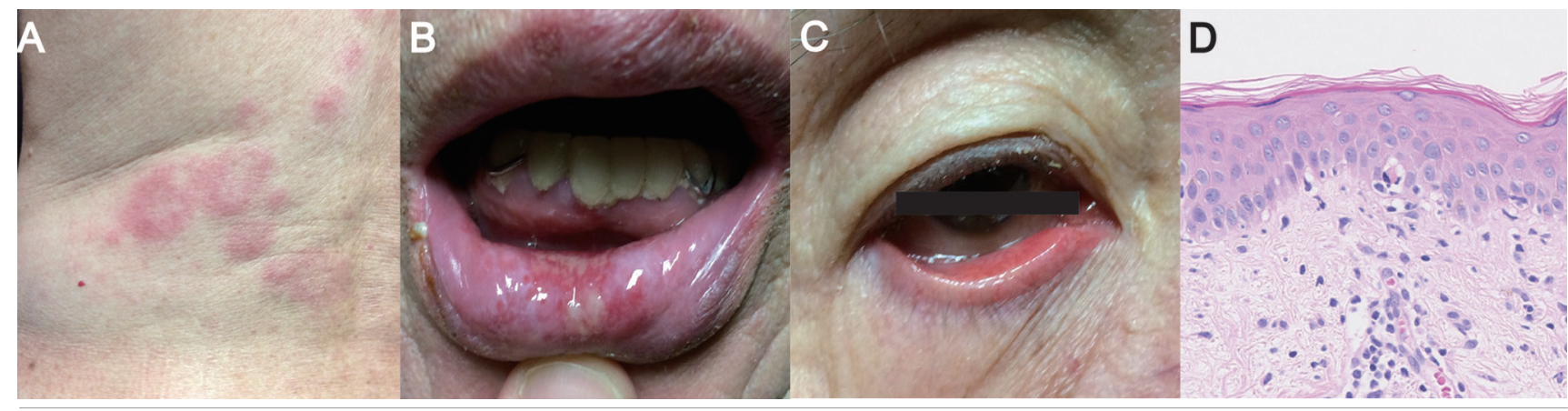

Figure. Clinical manifestations and histological examination. Annular erythema on the trunk (A), oral mucosa (B), and eyelid mucosa (C). D, Histology showing a dyskeratotic cell in the epidermis and lymphocytic infiltration in the epidermis and dermis. 


\section{Funding}

The authors declare that no funding was received for the present study.

\section{Conflicts of Interest}

The authors declare that they have no conflicts of interest.

\section{References}

1. Cannata J, Cuesta V, Peral V, Maisueche I, Herrera J. Reactivation of vasculitis after influenza vaccination. Br Med J. 1981;283(6290):526.

2. de Golian EW, Brennan CB, Davis LS. Lichenoid drug reaction following influenza vaccination in an HIV-positive patient: a case report and literature review. J Drugs Dermatol. 2014;13(7):873-5.
3. Fleming JD, Fogo AJ, Creamer DJ. Stevens-Johnson syndrome triggered by seasonal influenza vaccination and flucloxacillin: a pathogenetic hypothesis. Eur J Dermatol. 2011;21(3):434-5.

4. Noel I, Galloway A, Ive FA. Hypersensitivity to thiomersal in hepatitis B vaccine. Lancet. 1991;338(8768):705.

5. Heidary $N$, Cohen DE. Hypersensitivity reactions to vaccine components. Dermatitis. 2005;16(3):115-20.

Manuscript received March 2, 2017; accepted for publication May 4, 2017.

Yu Sawada Department of Dermatology University of Occupational and Environmental Health 1-1 Iseigaoka, Yahatanishi-ku, Kitakyushu 807-8555, Japan E-mail: long-ago@med.uoeh-u.ac.jp 